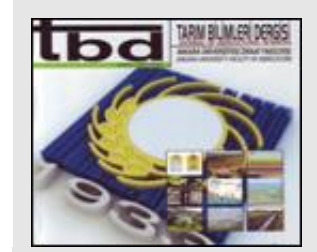

Tarım Bilimleri Dergisi

Journal of Agricultural Sciences

Tar. Bil. Der.

Dergi web sayfası:

www.agri.ankara.edu.tr/dergi

Journal homepage:

www.agri.ankara.edu.tr/journal

\title{
Effects of Race, Gender, Body Condition Score and Pregnancy on Serum Apelin Levels in Ewe
}

\author{
Bülent BAYRAKTAR ${ }^{a}$, Emre TEKCE ${ }^{b}$, Vecihi AKSAKAL ${ }^{b}$, Çiğdem TAKMA ${ }^{c}$, Fatma Gülten BAYRAKTAR ${ }^{\text {, }}$, Bülent \\ ŞENGÜL ${ }^{\mathrm{e}}$ \\ ${ }^{a}$ Bayburt University, Faculty of Health Sciences, Department of Physiotherapy and Rehabilitation, Bayburt, TURKEY \\ $\boldsymbol{b}_{\text {Bayburt University, School of Applied Sciences, Bayburt, TURKEY }}$

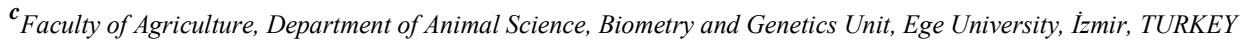 \\ $\boldsymbol{d}_{\text {Bayburt Provincial Directorate of Food Agriculture and Livestock, Bayburt, TURKEY }}$

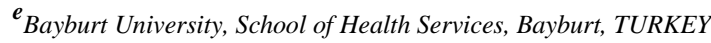

\author{
ARTICLE INFO \\ Research Article \\ Corresponding Author: Bülent BAYRAKTAR, E-mail: bulentbayraktar@bayburt.edu.tr, Tel: +90 (541) 8627442 \\ Received: 14 February 2019, Received in Revised Form: 28 May 2019, Accepted: 05 June 2019
}

\section{AUTHORS ORCID ID:}

(Bülent BAYRAKTAR: 0000-0002-2335-9089), (Emre TEKCE: 0000-0002-6690-725X), (Vecihi AKSAKAL: 0000-0001-5701-0726), (Çiğdem TAKMA: 0000-0001-8561-8333) , (Fatma Gülten BAYRAKTAR: 0000-0002-4661-8610), (Bülent ŞENGÜL: 0000-0002-99986564)

\begin{abstract}
Apelin is an important adipokine hormone that is released from adipose tissue, which is considered as the energy store of the body, which plays a role in many physiological processes in the body, as well as cardiovascular, immune functions and energy, nutrients and fluid metabolism. In this study, it was aimed to determine the effect of lactation, pregnancy and gender on apelin hormone levels in blood serums belonging to different races of ewe. In the present study, the hormone levels of the pregnant, non-pregnant ewe and rams of the
\end{abstract}

Keywords: Ewe; Apelin; Race; Gender; Pregnancy; ELISA

\begin{abstract}
Akkaraman Kangal and Morkaraman races were thin, with different body condition scores $(<2,3$ to 3.5 and $\geq 4)$. Apelin hormone level was determined by ELISA technique in blood serum samples of ewe's Jugular vein. It was determined that there was a difference in body scores between races and the interaction between race and body score was important $(\mathrm{P}<0.05)$. Apelin level in ewe in lactation and pregnant ewe did not change according to body condition scores $(\mathrm{P}>0.05)$. In terms of apelin, gender and body condition score, race and gender, and body condition score interactions were found to be significant.
\end{abstract}

\section{Introduction}

(C) Ankara Üniversitesi Ziraat Fakültesi

Adipose tissue is the source of circulating lipids, a metabolically active endocrine organ that is involved in the production and secretion of adipokines and has a role in energy homeostasis (Medina-Gómez 2012; Pérez-Pérez et al 2015).

Adipose tissue is categorized into three groups based on its structural characteristics: white, brown and beige adipose tissue (Awad \& Bradford 2010). White (unilocular) adipose tissue is an endocrine gland from which the adipokines are secreted, has a thin cytoplasmic section and the nuclei in the cells are pushed to the side. Brown adipose tissue (BAT) has numerous large mitochondria in its cytoplasm (Symonds 2013). The role of BAT in thermoregulation is to produce heat for thermogenesis via uncoupling protein-1 (UCP-1) instead of adenosine triphosphate (ATP) (Cinti 2012). UCP1 is only present in small amounts in the fetus and in ewe and humans. In neonatal lambs, it is activated with endocrine stimulating factors during delivery only at the beginning of respiration and to provide protection against severe hypothermia (Symonds et al 2003). Numerous endocrine factors including leptin (Mostyn et al 2002), catecholamines (Symonds et al 
2000), thyroid hormones (Heasman et al 2000), cortisol (Clarke et al 1998), and prolactin (Pearce et al 2005) have potential to activate BAT. In neonatal lambs, major BAT depots are found in the peri-abdominal and inguinal regions of lambs (Everett-Hincks \& Duncan 2008). Moreover, the anterior-scapular region and the subcutaneous tissues in the leg regions contain functional BAT (Jackson et al 2001).

Apelin hormone secreted from adipose tissue is a member of the hormone-cytokine family, which was discovered recently, isolated from the bovine gastric juice, originates from preproapelin and has a 77-amino acid precursor (Tatemoto et al 2001).

It has various isoforms such as apelin and APJ receptor, apelin-12, 13, 17, 36. The levels and localizations of these isoforms (APLN-12, 13, 17, 36) in the body vary according to the tissues (Kawamata et al 2001). Apelin/APJ is present in various brain areas (hypothalamic supraoptic nucleus; SON, paraventricular nucleus; PVN), heart, stomach, skeletal muscle, testicle and ovary (Hosoya et al 2000). Apelin-36 isoform is present at higher levels in the lung, testicle and uterus, while apelin-13 is present at higher levels in the mammary glands (Kawamata et al 2001). When the isoforms are analyzed in terms of action, apelin 13 isoform has 8 times more potent biological activity than apelin 17 and 60 times more potent biological activity than apelin 36 (Tatemoto et al 1998). Therefore, most of the recent studies were conducted on apelin-13 with a greater biological activity compared to other apelin isoforms and with $\mathrm{N}$-terminal pyroglutamate residues (Bełtowski 2006).

Apelin/APJ system is effective in important physiological processes including endocrine stress response (Taheri et al 2002; O'Carroll et al 2013), cardiovascular functions (Szokodi et al 2002), regulation of blood pressure (Tatemoto et al 2001), angiogenesis (Zhang et al 2016), thermoregulation (Reaux et al 2001) and regulation of energy metabolism (Bertrand et al 2015). One of the potential roles of apelin is the regulation of food intake. Due to the nutritional regimen, apelin and insulin secretion increase together with adipocytes (Boucher et al 2005). While intracerebro-ventricular injection of apelin does not affect food intake in satiated rats, it increases feed intake dose-dependently in hungry animals. This effect arising suggests that apelin has an anorectic effect (Brailoiu et al 2002). Therefore, possible changes in the amount of adipose tissue for a mammalian species result in important metabolic, immunological and endocrine problems.

The plasma level of apeline hormone, a member of the cell signaling protein group secreted by adipose tissue, called adipokines, is anticipated to be a potential serum biomarker that predicts the early diagnosis of diabetes mellitus (Ma et al 2014), cardiovascular diseases, obesity, and various types of cancer (Wysocka et al 2018).

Apelin/APJ is an important molecule and confirmation of its use as a biomarker in different diseases, determination of the potential of therapeutic strategies are a very important step for its clinical use. On the other hand, ewe races in Turkey is a branch of the livestock sector that has an important contribution to both economy and human nutrition (meat and milk production) (Yildiz \& Denk 2006). The lactation, reproduction and pregnancy periods are important stages in the production cycle for ewe races sustainability. For an effective reproduction process to ensure sustainability, genetic and endocrine control pathways should be known in detail. Lactation, one of the important stages affecting the production cycle, causes radical changes in the adipose tissue metabolism of ruminants. Apelin hormone, secreted from adipose tissue and found in the mammary gland, regulates the activity of mammary gland in ewe (Mercati et al 2018). In addition, primarily apelin, leptin, and adinopectin hormones in the adipokine group, and hormones such as growth hormone, prolactin and parathyroid hormone are secreted from the mammary gland. Some adipokines such as apelin, adiponectin and leptin have a role in the growth, function and lactogenic regulation of the mammary gland (Habata et al 1999; Palin et al 2017). Adipose tissue has a critical importance in meeting the metabolic energy required for lactation and in the strategies for increasing and improving the milk yield (Vernon \& Pond 1997) its ability to use adipose tissue energy (Lau et al 2005). The regulation of reproductive and nutritional behavior is controlled by the central effectors in the brain, the hypothalamus and the endocrine and nerve signals (Traslaviña et al 2014).

Apelin and APJ (G protein-coupled receptor) has a diffuse distribution in the reproductive areas of the brain such as hypothalamus, pituitary gland, and in the ovary and testicle. The role of apelin in the reproductive behavior and regulation of the hormone realizes the release of LH and FSH (Hosoya et al 2000). It has been reported that its regulatory role in male reproductive system suppresses the release of LH and testesterone (O'Carroll et al 2013; Sandal et al 2015).

The issue of infertility in rams is one of the most fundamental issues that affects the sustainability in ewe sector since it affects the reproductive performance in ewe, the number of ewe giving birth and lambs born per ewe. It is reported that apelin/apj agonist might be a useful drug in the treatment of infertility (Valle et al 2008). However, there is a limited number of studies investigating the effect of apelin hormone on male reproductive system. Another important stage in the production cycle is pregnancy. Pregnancy, is a period of intense physiological changes due to fetal growth. Protection of 
maternal and fetal health is very important in this period. If the body does not provide sufficient energy support required for the development of fetus or fetuses during pregnancy, other energy sources and body adipose depots are used. This process also corresponds to the lactation period. The energy source used in this period is glycogen reserves in the liver (Ağaoğlu \& Akgul 2006; Kaymaz 2006). The energy that cannot be met from carbohydrates is met from the fatty acids accumulated in the liver. If this accumulation is excessive, the liver functions are impaired, resulting in hepatic lipidosis, on the other hand, some fatty acids transform into toxic ketone bodies. Pregnancy toxemia occurs with the increased toxic ketones in blood, milk and urine and due to disorders in carbohydrate and fat metabolism (Rook 2000; Brozos et al 2011). Pregnancy toxemia, a metabolism and herd problem, most commonly results in death, if not diagnosed and treated timely. Therefore, attention should be paid to the feeding program from the $30^{\text {th }}$ day of pregnancy, especially in multiple pregnancies (Scott 2007). In the treatment of pregnancy toxemia, the administration of insulin increases the chance of recovery of animals with severe disease since it stimulates glucose intake (Henze et al 1998; Rook 2000). There is a strong link between apelin and insulin secretion (Guo et al 2009). The concentration of circulating apelin is directly increased by insulin, while it is reduced by glucocorticoids (Boucher et al 2005). Insulin acts directly on adipocytes to stimulate apelin production (Sörhede et al 2005). Apelin hormone modulates fetal angiogenesis and energy homeostasis during pregnancy. However, although its effect on pregnancy metabolism has not been fully clarified, it has an important role in providing a normal fetal development and in the regulation of placental vascularity and blood flow (Cobellis et al 2007; Telejko et al 2010). In a study conducted on experimental animals, it has been shown that the use of glucose was increased in the skeletal muscle and the plasma glucose level significantly decreased after acute apelin injection. With this aspect, apelin is considered as a promising development in the management of insulin resistance (Dray et al 2008).

The presence of apelin isoforms (Apelin 13, 17, 36) in plasma (Bełtowski 2006) allows the effect of apelin hormone to be analyzed, which forms the basis of our study. Therefore, the effect of race, lactation, pregnancy and gender factors on serum levels of apelin-13 isoform, which has been indicated to have a high biological activity in the literature, was investigated in our study. Fat in the tail of fat-tailed ewe is the fat stored in the tails of ewe raceed in regions with long winter season and limited possibility of feeding. It is also a reserve store of food and energy for ewe (Sönmez 1968; Anonymous 2012). Moreover, it is a human food containing quite high amounts of omega acids and the total fat and protein content of $100 \mathrm{~g}$ is 86.12 and $2.87 \mathrm{~g}$, respectively (TÜRKOMP 2019).

Clinical studies report that apelin hormone has a therapeutic potential in clinical use as a potential serum biomarker for the early diagnosis of various diseases (cancer, diabetes and cardiovascular problems) and follow-up of metabolic processes. The data obtained as a result of our current study is a preliminary study for the studies that we will conduct to investigate the therapeutic efficacy as a result of the use of synthetic apelin hormone among alternative treatment methods for pregnancy toxemia. Moreover, since this study on elucidating the factors affecting the level of apelin hormone is the first comparative and comprehensive study on domestic ewe, it will serve as a reference for further studies and provide new information to the literature. Furthermore, the studies to be conducted on large numbers of animals and different ewe races are of importance in terms of strategies. The aim of this study was to investigate the effect of gender, body condition score and race on serum apelin hormone levels of domestic ewe races (Akkaraman-Kangal and Morkaraman), during lactation and pregnancy periods.

\section{Material and Methods}

\subsection{Animal selection and creation of groups}

In the study, 270 ewes of Morkaraman and Akkaraman-Kangal races aged between two and seven with equal average live weight, gave normal birth in the previous reproductive season and 90 adult rams of Morkaraman and AkkaramanKangal-races were used.

The study was conducted in 6 ewe farms in Bayburt Province center and two districts (Demirozu and Aydintepe) $(40.16 \mathrm{~N}, 39.89-\mathrm{K} ; 40.22 \mathrm{~N}, 40.26-\mathrm{K} ; 40.3 \mathrm{~N}, 40.14-\mathrm{K})$ which ewe production is performed under intensive conditions and records are regularly followed up. The animals used in the study were divided into three groups as Group I (lactation group), ewes in the early lactation period ( $n=90)$ ) Group II (pregnancy group), ewes in the first period of pregnancy (on the $100^{\text {th }}$ day of first pregnancy) $(n=90)$ and Group III (rams) by randomization so that the average total live weight of the groups was equal. During the study period, the environment and feed factor (Table 1) were taken into account. The content of feeds used in this study was analyzed according to the standard AOAC methods. 
Table 1- Nutrient composition of diets used in the study (\%)

\begin{tabular}{lcc}
\hline Ration composition & Morkaraman & Kangal Akkaraman \\
\hline Barley & 65.00 & 65.00 \\
Wheat bran & 10.50 & 7.00 \\
Soybean meal & 22.00 & 20.50 \\
Dicalciumphosphate & 1.00 & 1.00 \\
Salt & 0.50 & 0.50 \\
Premix & 0.50 & 0.50 \\
\hline Chemical composition, $\%$ & & \\
\hline Dry Matter & 90.39 & 90.60 \\
Crude protein & 17.37 & 16.99 \\
Crude ash & 5.59 & 5.78 \\
ADF & 8.84 & 11.26 \\
NDF & 34.44 & 32.72 \\
ME Kcal kg-1 & 2642 & 2620 \\
\hline
\end{tabular}

$1 \mathrm{~kg}$ vit.-min. Premix contains vitamin A, 7,000,000 IU; vitamin D3, 1,000,000; vitamin E, 30,000; Mn, 50,000 mg; Zn, 50,000 mg; Fe, 50,000; Cu, $10,000 \mathrm{mg} ; \mathrm{I}, 8,000 \mathrm{mg}$; Co, $200 \mathrm{mg}$; Se, $150 \mathrm{mg}$; and Mg, $100 \mathrm{mg}$

\subsection{Collection of serum samples}

Blood sample of $10 \mathrm{~mL}$ was collected from the jugular vein of the ewe into the tubes not containing anticoagulant (VACUETTE® TUBE $9 \mathrm{~mL}$ Serum Clot Activator). The blood samples collected were centrifuged at $3000 \mathrm{rpm} / \mathrm{min}$ for 10 minutes on a refrigerated centrifuge (NF 1200, NUVE, Ankara, Turkey) in the laboratory, then resulting blood serums were separated. The separated serums were transferred into sterile tubes and stored in deep freezers $\left(-80^{\circ} \mathrm{C}\right)$ until the laboratory analyses were carried out.

\subsection{Measurement of apelin hormone levels in serum}

The basic principle of the Elisa method is based on the use of enzyme to determine the antigen-antibody combination in the sample. The enzyme used converts the colorless layer (chromogen) into a colored product, indicating the presence of antigen-antibody, and the intensity of the resulting color is read by the elisa plate reader at the recommended wavelength so the relevant concentration is determined (Marai et al 2001).

The minimum detectable concentration of the apelin hormone kit used in the measurement of apelin levels in the blood serums obtained as a result of the study is reported as $<18.75 \mathrm{pg} \mathrm{mL}^{-1}$. The race-specific ewe APLN ELISA Kit (Apelin, FineTest, Product code: ESH0081, CHINA) was studied in accordance with the procedure described in the manufacturer's catalog using the determination of $31.25-2000 \mathrm{pg} \mathrm{mL}^{-1}$, the intra assay coefficient of $8.0 \%$ and the interassay coefficient of $10.0 \%$.

\subsection{Statistical analysis}

In this study, the serum apelin hormone levels of Kangal Akkaraman and Morkaraman ewe races in the lactation and pregnancy period were analyzed as dependent variables and gender, body score and race factors were analyzed as fixed effects. In the analysis of the effects of gender, body score and race on the serum apelin hormone levels of Kangal Akkaraman and Morkaraman ewe races in the lactation and pregnancy period, normality test was applied to the apelin measurements. As a result of significant Shapiro Wilk test, logarithmic transformation was applied to the data. After the transformation process, Levene's test $(\mathrm{P}=0.33)$ was used to determine whether the data was normally distributed and the group variances were homogenous. Then, the univariate procedure was used in the generalized linear models for the logarithmic apelin measurements. The analyses were performed in the full factorial setting with 3 factors $(2 \times 3 \times 3)$ according to completely randomized design, and the interaction effects of the body score and race, body score and gender, race and gender, and body score, gender and race were also investigated. Tukey's multiple comparison test was used to compare the differences for the means of apelin hormone. IBM SPSS v25 statistical package software was used in all analyses in this study. All significant differences were evaluated by testing at $\mathrm{P}<0.05$ level. 


\section{Results}

Kangal Akkaraman and Morkaraman ewe with a body condition score of $\leq 2$ (low), 3- 3,5 (optimal), and $\geq 4$ (high). The treatment groups were: Group 1; non-pregnant $(n=90)$; Group 2 pregnant $(n=90)$ and Group 3, rams $(n=90)$. The experimental material was composed of animals of similar ages. At the end of the research, when the apelin level of the coaches was examined according to the races and body condition score (Table 2), it was determined that there was a bodyscore difference according to the races, while it was found to be important in the apelin-related interaction between race and body score (Table 3). In the study conducted on the ewe, it was found that the apelin level in the lactation and pregnancy period was similar in terms of body condition score (Table 3 and 4), but it was determined that there was a difference between races. As a result of the statistical analysis, it was found that the effect of the apple's gender on the body condition score, the race's gender and race's body condition score interaction $(\mathrm{P}<0.05)($ Table 4$)$.

Table 2- Effect of apelin on ram races and body condition score $\left(\mathrm{ng} \mathbf{~ m L}^{-1}\right)$

\begin{tabular}{lrrr}
\hline & $N$ & Morkaraman & Kangal Akkaraman \\
\hline 2 Bodyscore & 30 & $5.60 \pm 0.54^{\mathrm{a}}$ & $4.43 \pm 0.34^{\mathrm{ab}}$ \\
3 Bodyscore & 30 & $3.31 \pm 0.54^{\mathrm{bc}}$ & $4.85 \pm 0.39^{\mathrm{ab}}$ \\
4 Bodyscore & 30 & $4.04 \pm 0.34^{\mathrm{abc}}$ & $3.22 \pm 0.22^{\mathrm{c}}$ \\
\hline Source of variation $(P$-values $)$ & & \\
\hline Race & & 0.66 \\
Bodyscore & $0.00^{* *}$ & \\
Race $\times$ Bodyscore & & \\
\hline Main effect means diet & & \\
\hline 2 Bodyscore & $3.99 \pm 0.18^{\mathrm{a}}$ \\
3 Bodyscore & $3.86 \pm 0.18^{\mathrm{ab}}$ \\
4 Bodyscore & $3.74 \pm 0.14^{\mathrm{b}}$ \\
\hline Race & & \\
\hline Morkaraman & $4.17 \pm 0.19$ \\
Kangal Akkaraman & & \\
\hline
\end{tabular}

Table 3- Effect of apelin on pregnancy and body condition score in pregnancy $\left(\mathrm{ng} \mathrm{mL}^{-1}\right)$

\begin{tabular}{|c|c|c|c|c|}
\hline & $N$ & Morkaraman & & Kangal Akkaraman \\
\hline 2 Bodyscore & 30 & $4.55 \pm 0.58$ & & $4.32 \pm 0.47$ \\
\hline 3 Bodyscore & 30 & $4.75 \pm 0.58$ & & $5.47 \pm 0.37$ \\
\hline 4 Bodyscore & 30 & $4.45 \pm 0.52$ & & $5.61 \pm 0.36$ \\
\hline \multicolumn{5}{|c|}{ Source of variation (P-values) } \\
\hline Race & & & 0.18 & \\
\hline Bodyscore & & & 0.35 & \\
\hline Race $\times$ Bodyscore & & & 0.37 & \\
\hline \multicolumn{5}{|c|}{ Main effect means diet } \\
\hline 2 Bodyscore & & & $4.43 \pm 0.37$ & \\
\hline 3 Bodyscore & & & $5.11 \pm 0.34$ & \\
\hline 4 Bodyscore & & & $5.03 \pm 0.31$ & \\
\hline \multicolumn{5}{|l|}{ Race } \\
\hline Morkaraman & & & $4.58 \pm 0.32$ & \\
\hline Kangal Akkaraman & & & $5.14 \pm 0.23$ & \\
\hline
\end{tabular}


Table 4- Simultaneous comparison of apelin in ewe and rams Interaction of gender, races and body condition score (ng $\left.\mathbf{m L}^{-1}\right)$

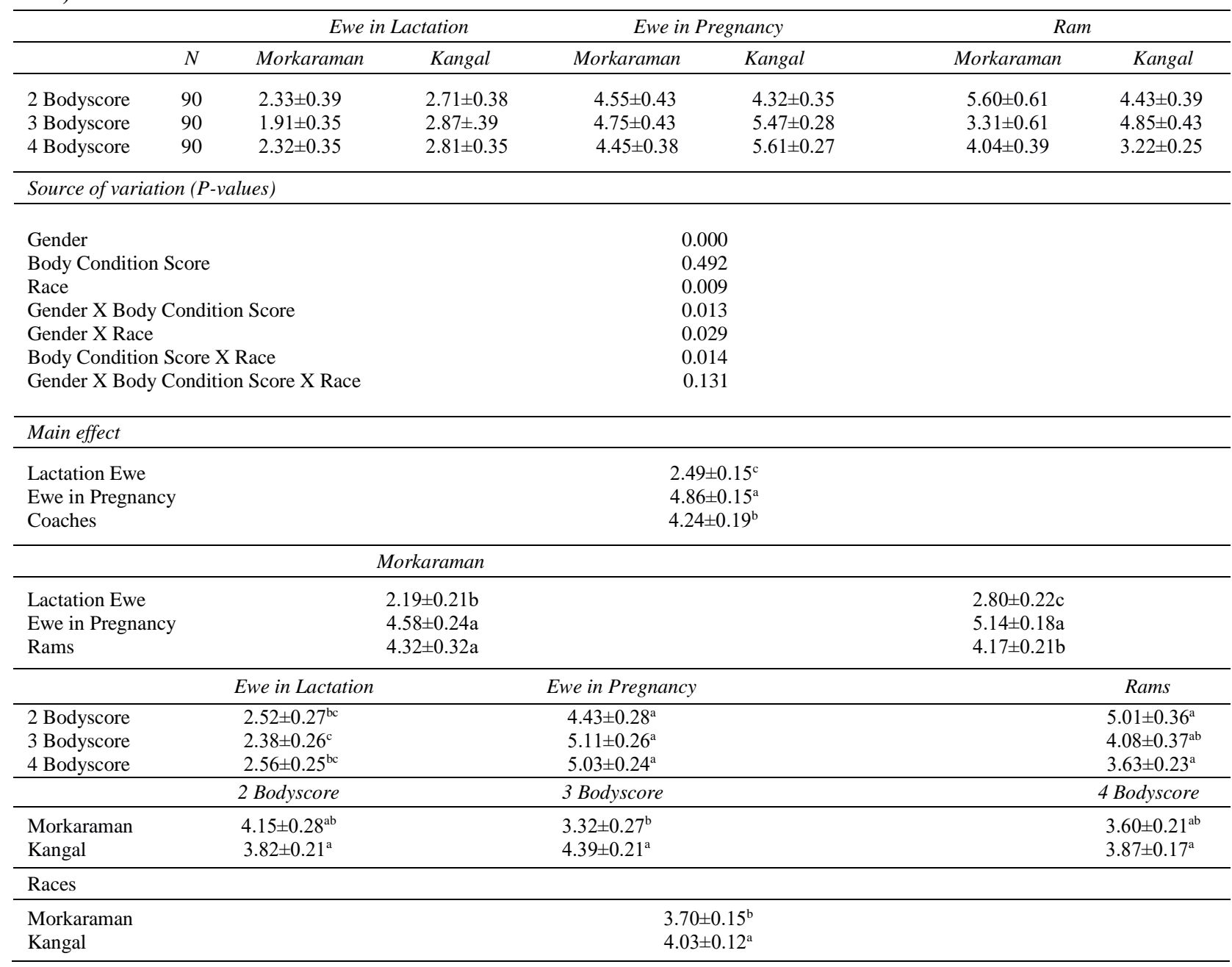

\section{Discussion and Conclusions}

Pregnancy and lactation are important processes involving physiological and hormonal changes. The mammary gland is subject to physiological changes both during pregnancy and postpartum period lactation. Endocrine gland mammary gland, especially apelin, leptin, adiponectin hormones, especially growth hormone, prolactin, hormones such as parathyroid are secreted (Habata et al 1999; Palin et al 2017). Apelin hormone originating from adipose tissue; body mass index, depending on the secretion of adipose tissue, varies according to many physiological periods such as pregnancy, lactation (Lérias et al 2014; Hughes \& Watson 2018). In our current study, it was found that the relationship of race, lactation, pregnancy and gender with apelin hormone level in ewes was not investigated in the literature and there was no study in this regard.

As a result of clinical studies, it has been reported that apelin hormone has a therapeutic potential in clinical use as a potential serum biomarker in the early diagnosis of various diseases (cancer, diabetes, cardiovascular) and follow-up of metabolic processes (Ma et al 2014; Mutlak et al 2018; Wysocka et al 2018; Diakowska et al 2019). In the studies on rats, it was reported that the level of apelin in breast tissue increased during pregnancy and lactation, but reached the maximum level during the delivery period and decreased during lactation (Habata et al 1999; Clarkson et al 2004; Mercati et al 2018). In the studies on ruminants, it was stated that apelin levels of ewes with a body condition score of 2 were higher in the blooming period of range land compared to the period of dry grass, and that apelin levels decreased in the postpartum period (Mercati et al 2018). In our study, serum apelin levels of ewes of different races (Morkaraman and Kangal Akkaraman) with different body condition scores $(<2,3,3.5$, and $\geq 4)$ in the lactation and pregnancy period and serum apelin levels of rams were investigated. In our study, it was determined that the apelin level of those with a body 
condition score of $<2$ in rams of Morkaraman race was high, whereas there was no difference in Kangal Akkaraman race; when the interaction between them was analyzed, it was found that there was difference between rams on the basis of race according to the body condition score, and that the interaction of race $\mathrm{x}$ body condition score was significant $(\mathrm{P}<0.05)$, and this difference did not exhibit the same tendency between the ram races in the groups with the same body condition scores. According to the result of the analysis on pregnancy, it was determined that pregnancy did not have any effect on body condition score in animal races. Whereas in the lactation period, apelin levels varied according to the races, and it was determined that apelin was higher in Kangal Akkaraman race. In the lactation period, the apelin levels were found to be similar in the body condition score groups. The apelin levels in the body condition score groups of races had the similar tendency and no interaction effect was found (Table 5). In addition to that, apelin levels were simultaneously compared between the ewes in lactation and pregnancy period and rams. A statistically significant difference was determined in terms of different gender groups and races created according to this. On the other hand, the effect of apellin on the interaction of race-sex, body condition scores- sex and body condition score on race was found to be statistically significant. According to these results, apelin levels in the same race but in different gender groups or at different body condition score groups did not change.

Therefore, when we examined similar studies, the same results were obtained (Mercati et al 2018), however, studies on different species things have shown different results (Habata et al 1999; Clarkson et al 2004). This dissimilarity can be attributed by species differency and it can also be explained by the continuation of secretory activation from breast tissue in the dry period in ruminants, unlike other species (Holst et al 1987;Sordillo and Nickerson 1988; Mercati et al 2018). In the light of the results obtained from our current study, we can predict early diagnosis and prevention of metabolic diseases such as pregnancy toxemia. However, it is thought that the continuation of studies on large numbers of animals and different sheep races will benefit in understanding the physiological mechanisms and the strategies that can be developed for this mechanism.

\section{Acknowledgements}

This study was supported by Bayburt University Scientific Research Projects Unit (2017/02-69001-08). In addition, the abstract of this study was published on 13 December 2018 in acta physologica (ISSN: 1748-1708).

\section{References}

Ağaoğlu Z T \& Akgül Y (2006). Koyunların ketozisi. “Geviş Getiren Hayvanların İç Hastalıkları”, 2. Baskı, Ed; Gül Y, Medipres, Malatya

Anonim (2012). Küçükbaş hayvancılık çalıştay raporu. Doğu Anadolu Kalkınma Ajansı.8-9 Haziran 2012. Hakkari. 64 s

Awad A B \& Bradford P G (2010). Adipose tissue and inflammation. Bask1 no: 978-1-4200-9130-4. U.S. Taylor and Francis Group

Bełtowski J (2006). Apelin and visfatin: unique. Medical Science Monitor 12(6): RA112-RA119

Bertrand C, Valet P \& Castan-Laurell I (2015). Apelin and energy metabolism. Frontiers in physiology 6: 115

Boucher J, Masri B \& Daviaud D (2005). Apelin, a newly identified adipokine up-regulated by insulin and obesity. Endocrinology 146: $1764-1771$

Brailoiu G C, Dun S L, Yang J, Ohsawa M, Chang J K \& Dun N J (2002). Apelin-immunoreactivity in the rat hypothalamus and pituitary. Neuroscience Letters 327(3): 193-197

Brozos C, Mavrogianni V S \& Fthenakis G C (2011). Treatment and control of peri-parturient metabolic diseases: pregnancy toxemia, hypocalcemia, hypomagnesemia. Veterinary Clinics: Food Animal Practice 27(1): 105-113

Cinti S (2012).The Adipose organ at glance. Disease Models Mechanisms 5(5): 588-594

Clarke L, Heasman L \& Symonds M E (1998). Influence of maternal dexamethasone administration on thermoregulation in lambs delivered by caesarean section. Journal of Endocrinology 156(2): 307-314

Clarkson R W, Wayland M T, Lee J, Freeman T \& Watson C J (2004). Gene expression profiling of mammary gland development reveals putative roles for death receptors and immune mediators in post-lactational regression. Breast Cancer Research 6(2): R92

Journal of Agricultural Sciences (Tarım Bilimleri Dergisi) 26 (2020) 363-372 
Cobellis L, De Falco M, Mastrogiacomo A, Giraldi D, Dattilo D, Scaffa C \& De Luca A (2007). Modulation of apelin and APJ receptor in normal and preeclampsia-complicated placentas. Histology and Histopathology 22(1-3): 1-8

Diakowska D, Markocka-Mączka K, Nienartowicz M, Rosińczuk J \& Krzystek-Korpacka M (2019). Assessment of apelin, apelin receptor, resistin, and adiponectin levels in the primary tumor and serum of patients with esophageal squamous cell carcinoma. Advances in Clinical and Experimental Medicine: Official Organ Wroclaw Medical University. 28(5): 671-678

Dray C, Knauf C, Daviaud D, Waget A, Boucher J, Buléon M \& Burcelin R (2008). Apelin stimulates glucose utilization in normal and obese insulin-resistant mice. Cell Metabolism 8(5): 437-445

Everett-Hincks J M \& Duncan S J (2008). Lamb post-mortem protocol for use on farm: to diagnose primary cause of lamb death from birth to 3 days of age. The Open Veterinary Science Journal 2(1):55-62

Guo L, Li Q, Wang W, Yu P, Pan H, Li P \& Zhang J (2009). Apelin inhibits insulin secretion in pancreatic $\beta$-cells by activation of PI3-kinase-phosphodiesterase 3B. Endocrine Research 34(4): 142-154

Jackson I T, Simman R, Tholen R \& DiNick V D (2001). A successful long-term method of fat grafting: Recontouring of a large subcutaneous postradiation thigh defect with autologous fat transplantation. Aesthetic Plastic Surgery 25(3): 165-169

Habata Y, Fujii R, Hosoya M, Fukusumi S, Kawamata Y, Hinuma S \& Onda H (1999). Apelin, the natural ligand of the orphan receptor APJ, is abundantly secreted in the colostrum. Biochimica et Biophysica Acta (BBA)-Molecular Cell Research 1452(1): 25-35

Holst B D, Hurley W L \& Nelson D R (1987). Involution of the bovine mammary gland: Histological and ultrastructural changes. Journal of Dairy Science 70: 935-944

Hosoya M, Kawamata Y, Fukusumi S, Fujii R, Habata Y, Hinuma S \& Nishimura O (2000). Molecular and functional characteristics of APJ tissue distribution of mRNA and interaction with the endogenous ligand apelin. Journal of Biological Chemistry 275(28): 21061-21067

Hughes K \& Watson C J (2018). The mammary microenvironment in mastitis in humans, dairy ruminants, rabbits and rodents: A one health focus. Journal of Mammary Gland Biology and Neoplasia 23: 27-41

Kawamata Y, Habata Y, Fukusumi S, Hosoya M, Fujii R, Hinuma S \& Fujino M (2001). Molecular properties of apelin: tissue distribution and receptor binding. Biochimica et Biophysica Acta (BBA)-Molecular Cell Research 1538(2-3): 162-171

Kaymaz A A (2006). Koyunların gebelik toksemisi. “Geviş Getiren Hayvanların İç Hastalıkları”, 2. Baskı, Ed; Gül Y, Medipres, Malatya

Lau D C, Dhillon B, Yan H, Szmitko P E \& Verma S (2005). Adipokines: molecular links between obesity and atheroslcerosis. American Journal of Physiology-Heart and Circulatory Physiology 288(5): H2031-H2041

Lérias J R, Hernández-Castellano L E, Suárez-Trujillo A, Castro N, Pourlis A \& Almeida A M (2014). The mammary gland in small ruminants: Major morphological and functional events underlying milk production-A review. Journal of Dairy Research 81: $304-$ 318

Ma W Y, Yu T Y, Wei J N, Hung C S, Lin M S, Liao Y J \& Lin C H (2014). Plasma apelin: a novel biomarker for predicting diabetes. Clinica Chimica Acta 435: 18-23

Medina-Gómez G (2012). Mitochondria and endocrine function of adipose tissue. Best Practice \& Research Clinical Endocrinology \& Metabolism 26(6): 791-804

Mercati F, Maranesi M, Dall'Aglio C, Petrucci L, Pasquariello R, Tardella F \& Scocco P (2018). Apelin system in mammary gland of sheep reared in semi-natural pastures of the central Apennines. Animals 8(12): 223

Mostyn A, Bispham J, Pearce S, Evens Y, Raver N, Keisler D H \& Symonds M E (2002). Differential effects of leptin on thermoregulation and uncoupling protein abundance in the neonatal lamb. The FASEB Journal 16(11): 1438-1440

Mutlak S S, Kadhim M S \& Hussein R M (2018). Apelin and some biomarkers in females with metabolic syndrome. Biomedical and Pharmacology Journal 11(1): 247-253

O'Carroll A M, Lolait S J, Harris L E \& Pope G R (2013). The apelin receptor APJ: journey from an orphan to a multifaceted regulator of homeostasis. Journal of Endocrinology 219(1): R13-R35 
Palin M F, Farmer C \& Duarte C R A (2017). Triennial lactation symposium/bolfa: Adipokines affect mammary growth and function in farm animals. Journal of Animal Science 95(12): 5689-5700

Pearce S, Budge H, Mostyn A, Genever E, Webb R, Ingleton P \& Stephenson T (2005). Prolactin, the prolactin receptor and uncoupling protein abundance and function in adipose tissue during development in young sheep. Journal of Endocrinology 184(2): 351-359

Pérez-Pérez A, Sánchez-Jiménez F, Maymó J, Dueñas J L, Varone C \& Sánchez-Margalet V (2015). Role of leptin in female reproduction. Clinical Chemistry and Laboratory Medicine (CCLM) 53(1): 15-28

Reaux A, De Mota N, Skultetyova I, Lenkei Z, El Messari S, Gallatz K \& Llorens-Cortès C (2001). Physiological role of a novel neuropeptide, apelin, and its receptor in the rat brain. Journal of Neurochemistry 77(4): 1085-1096

Rook J S (2000). Pregnancy toxemia of ewes, does, and beef cows. Veterinary Clinics of North America: Food Animal Practice 16(2): 293-317

Sandal S, Tekin S, Seker F B, Beytur A, Vardi N, Colak C \& Yilmaz B (2015). The effects of intracerebroventricular infusion of apelin13 on reproductive function in male rats. Neuroscience Letters 602: 133-138

Scott P R (2007). Metabolic disorders and trace element deficiencies. Sheep Medicine”, Manson Publishing, London, UK

Sönmez R (1968). Koyunculuk ve Yapağı. Ege Üniversitesi Ziraat Fakültesi Yayınları, No: 108, lzmir

Symonds M E (2013). Brown adipose tissue growth and development. Scientifica 2013:1-14

Symonds M E, Bird J A, Sullivan C, Wilson V, Clarke L \& Stephenson T (2000). Effect of delivery temperature on endocrine stimulation of thermoregulation in lambs born by cesarean section. Journal of Applied Physiology 88(1): 47-53

Symonds M E, Mostyn A, Pearce S, Budge H \& Stephenson T (2003). Endocrine and nutritional regulation of fetal adipose tissue development. The Journal of Endocrinology 179(3): 293-299

Szokodi I, Tavi P, Földes G, Voutilainen-Myllylä S, Ilves M, Tokola H \& Ruskoaho H (2002). Apelin, the novel endogenous ligand of the orphan receptor APJ, regulates cardiac contractility. Circulation Research 91(5): 434-440

Taheri S, Murphy K, Cohen M, Sujkovic E, Kennedy A, Dhillo W \& Bloom S (2002). The effects of centrally administered apelin-13 on food intake, water intake and pituitary hormone release in rats. Biochemical and Biophysical Research Communications 291(5): $1208-1212$

Tatemoto K, Hosoya M, Habata Y, Fujii R, Kakegawa T, Zou M X \& Kurokawa T (1998). Isolation and characterization of a novel endogenous peptide ligand for the human APJ receptor. Biochemical and Biophysical Research Communications 251(2): $471-476$

Tatemoto K, Takayama K, Zou MX, Kumaki I, Zhang W, Kumano K, \& Fujimiya M (2001).The novel peptide Apelin lowers blood pressure via a nitric oxide-dependent mechanism. Regulatory peptides 99: 87- 92

Telejko B, Kuzmicki M, Wawrusiewicz-Kurylonek N, Szamatowicz J, Nikolajuk A, Zonenberg A \& Wilczynski J (2010). Plasma apelin levels and apelin/APJ mRNA expression in patients with gestational diabetes mellitus. Diabetes Research and Clinical Practice 87(2): 176-183

Traslaviña G A A, de Oliveira F L \& Franci C R (2014). Early adolescent stress alters behavior and the HPA axis response in male and female adult rats: the relevance of the nature and duration of the stressor. Physiology \& Behavior 133: 178-189

TÜRKOMP (2019). Ulusal Gıda Kompozisyon Veri Tabanı. http://www.turkomp.gov.tr/food-koyun-kuyruk-yagi-80 (Accessed: 27.03.2019)

Valle A, Hoggard N, Adams A C, Roca P \& Speakman J R (2008). Chronic central administration of apelin-13 over 10 days increases food intake, body weight, locomotor activity and body temperature in C57BL/6 mice. Journal of Neuroendocrinology 20(1): 7984

Vernon R G \& Pond C M (1997). Adaptations of maternal adipose tissue to lactation. Journal of Mammary Gland Biology and Neoplasia 2(3): 231-241 
Yıldız N \& Denk H (2006). Van yöresinde halk elinde yetiştirilen Akkaraman koyunlarının çeşitli verim özelliklerinin araştırılması II. Kirli yapağı verimleri, lüle uzunlukları, beden ölçüleri, kuzuların doğum ağılıkları ve yasama güçleri. Fırat Üniversitesi Sağllk Bilimleri Dergisi 20(1): 29-37

Wysocka M B, Pietraszek-Gremplewicz K \& Nowak D (2018). The role of apelin in cardiovascular diseases, obesity and cancer. Frontiers in Physiology 9: 557-572

Zhang J, Liu Q, Fang Z, Hu X, Huang F, Tang L \& Zhou S (2016). Hypoxia induces the proliferation of endothelial progenitor cells via upregulation of Apelin/APLNR/MAPK signaling. Molecular Medicine Reports 13(2): 1801-1806 